ARTIKEL

PENELITIAN PNBP FIP UNM

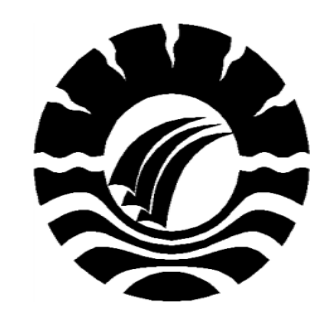

ANALISIS PEMENUHAN STANDAR PELAYANAN MINIMAL SEKOLAH LUAR BIASA TUNAGRAHITA

DI KOTA MAKASSAR

Ketua/Anggota Tim :

Dr. Triyanto Pristiwaluyo , M. Pd,/0005085911

Drs. H. Syamsuddin, M.Si,/0031126270

Drs. M. Shodiq AM., M. Pd./0002075714 


\title{
ANALISIS PEMENUHAN STANDAR PELAYANAN MINIMAL SEKOLAH LUAR BIASA TUNAGRAHITA DI KOTA MAKASSAR
}

\section{ANALYSIS OF FULFILLMENT OF MINIMUM SERVICE STANDARDS SPECIAL SCHOOL MENTALLY RETARDED IN MAKASSAR}

\author{
Oleh : ${ }^{1}$ \\ Dr. Triyanto Pristiwaluyo, M. Pd \\ Drs. H. Syamsuddin, M.Si \\ Drs. M. Shodiq, AM., M. Pd.
}

\begin{abstract}
ABSTRAK
Penelitian ini penelitian deskriptif analitis. Tujuan penelitian ini adalah untuk mengetahui keterpenuhan Standar Pelayanan Minimal Sekolah Luar Biasa Tunagrahita di Kota Makassar. Populasi dalam penelitian ini adalah semua sekolah luar biasa yang menyelenggarakan pendidikan bagi peserta didik tunagrahita di Kota Makassar. Mengingat populasi masih dalam jangkauan peneliti, maka dalam penelitian ini tidak dilakukan penarikan sampel. Data dikumpulkan melalui kuesioner dan dianalisis dengan menggunakan statistik deskriptif,. Hasil penelitian menunjukkan bahwa Sekolah khusus (SLB) Gangguan inteketual di Kota Makassar belum semuanya memenuhi Standar Isi. Masih ada Sekolah yang belum mengimplementasikan program kemandirian/persiapan kerja. Pemerintah Daerah belum melalukan peran dalam pemenuhan standar isi. Sekolah khusus (SLB) Gangguan inteketual di Kota Makassar telah memenuhi Standar Kompetensi Lulusan. Standar Proses Sekolah khusus (SLB) Gangguan inteketual di Kota Makassar belum sepenuhnya memenuhi Standar Proses. Pemerintah daerah Kota Makassar belum sepernuhnya berperan dalam pemenuhan Standar Proses Sekolah khusus (SLB) Gangguan inteketual. Dukungan Pemerintah Daerah sangat diharapkan dalam hal pengadaan buku teks pelajaran dan buku guru untuk peserta didik gangguan inteketual yang ditetapkan oleh Pemerintah. Sekolah khusus (SLB) Gangguan inteketual di Kota Makassar belum sepenuhnya memenuhi Standar Pendidik dan Tenaga Kependidikan. Terutama dalam hal kualifikasi akademik Kepala Sekolah. Pemerintah Daerah kurang berperan dalam pemenuhan standar Pendidik dan Tenaga Kependidikan Sekolah Luar (SLB) Gangguan inteketual di Kota Makassar. Standar Sarana dan Prasarana belum sepenuhnya memenuhi oleh Sekolah khusus (SLB) Gangguan inteketual di Kota Makassar. Peran Pemerin Daerah dalam pemenuhan standar Sarana dan Prasarana Sekolah khusus (SLB) Gangguan inteketual di Kota Makassar juga masih rendah. Sekolah khusus (SLB) Gangguan inteketual di Kota Makassar belum sepenuhnya memenuhi Standar Pengelolaan. Pemerintah Daerah belum memfasilitasi Sekolah dalam pemenuhan stnadar pengelolaan sekolah. Sekolah khusus (SLB) Gangguan inteketual di Kota Makassar telah memenuhi Standar Penilaian Pendidik.
\end{abstract}

\footnotetext{
${ }^{1}$ Dosen Jurusan Pendidikan Luar Biasa FIP UNM
} 


\begin{abstract}
This is a descriptive analytical research. The purpose of this study was to determine the fulfillment of minimum service standards Special School of intellectual disorders in Makassar. The population in this study are all special schools that provide education for students intellectual disorders in Makassar. Given the population is still within reach of researchers, so in this study was not carried sampling. Data were collected through a questionnaire and analyzed using descriptive statistic.

The results stated that the School (SLB) intellectual disorders in Makassar do not all fulfill Content Standards. There are still schools that have not implemented a program of preparation for independence or work. Local Government has not been play a part in the fulfillment of content standards.Special School (SLB) on intellectual disorders in Makassar has fulfilled Competency Standards of Graduates. School (SLB) intellectual disorders in Makassar not meet the standards process. Local government has not fully play a role in fulfillment the standard process of School (SLB) intellectual disorders. Local government support is expected in the procurement of textbooks and teachers' guides for learners with impaired inteketual. School (SLB) Intellectual Disorders in Makassar do not meet the standards of Teachers and Education Personnel. Especially in terms of academic qualifications principals. The local government has not been play a role in fulfilling the standards of Teachers and Education Personnel Special School (SLB) inteketual disorders in Makassar. Infrastructure standards have not been complied with by the Special School (SLB) inteketual disorders in Makassar. The Role of Local Government in fulfilling the standards of Infrastructures Special School (SLB) Intellectual disordersin Makassar is still low. Special School (SLB) Intellectual disorders in Makassar has not complied with management standard. Local government is not providing facilities to the school in compliance with school management standards. Special School (SLB) Intellectual disorder sin Makassar has fulfilled Educator Assessment Standards.
\end{abstract}

Key words: minimum service standards, special school (SLB) 


\section{PENDAHULUAN}

Undang-undang Dasar 1945 (amandemen) pasal 31, mengamanatkan bahwa setiap warga negara berhak mendapat pendidikan tanpa terkecuali, termasuk anak tunagrahita. Anak tunagrahita adalah anak yang memiliki fungsi intelektual signifikan dibawah rata-rata, yang disertai dengan adanya gangguan penyesuaian diri dengan lingkungan, yang terjadi sebelum usia 18 tahun.

Ketunagrahitaan merupakan suat kondisi yang dapat menimbulkan permasalahan bagi penyandangnya apabila mereka tidak memperoleh dukungan dan bantuan yang diperlukannya. Upaya memberikan layanan bagi anak tunagrahita dimaksudkan agar mereka dapat memperoleh layanan sesuai dengan ketunagrahitaan yang dimilikinya sehingga mereka dapat mengembangkan potensi yang dimilikinya secara optimal. Upaya ini dapat dilakukan oleh pemerintah disertai dengan dukungan dan peran serta dari orang tua maupun masyarakat, sebagai wujud tanggung jawab memenuhi tuntutan terhadap pendidikan untuk semua (education for all).

Pendidikan anak tunagrahita merupakan bagian integral dari pendidikan pada umumnya, dengan kekhususan memberi kesempatan secara maksimal bagi anak tunagrahita untuk berfungsi sesuai dengan potensinya, dengan harapan bahwa pada suatu saat anak juga akan memberi sumbangan yang maksimal bagi peningkatan kehidupan sesuai dengan aktualisasi potensinya itu. Hal itu sesuai dengan citra masyarakat yang kita anut dengan memperhatikan kaitan fungsional antara individu dengan masyarakat.

Sesuai dengan Renstra Kemendikbud 2010 - 2014 bahwa visi Indonesia tahun 2025 adalah mengangkat Indonesia menjadi negara maju dan merupakan kekuatan 12 besar dunia di tahun 2025 dan 8 besar dunia di tahun 2045 melalui pertumbuhan ekonomi tinggi yang inklusif dan berkelanjutan. Berdasarkan pada renstra Kemendikbud tersebut maka pengembangan SDM merupakan hal yang sangat strategis. Oleh karena itu, segala upaya yang berkaitan dengan pembinaan dan pengembangan SDM perlu mendapat prioritas dukungan dari berbagai pihak, baik Pemerintah, Masyarakat, maupun Dunia Usaha.

Upaya memberikan layanan bagi anak tunagrahita agar mereka dapat memperoleh layanan sesuai dengan ketunagrahitaan yang dimilikinya terus diupayakan baik oleh pemerintah pusat maupun pemerintah daerah dan/atau swasta. Untuk itu, perlu perluasan dan peningkatan akses dan mutu pembinaan bagi anak tunagrahita usia sekolah. Kualitas layanan yang dilaksanakan oleh sekolah untuk peserta didik tunagrahita hendaknya memenuhi Standar Pelayanan Minimal (SPM) untuk Sekolah Luar Biasa Tunagrahita. Untuk menjamin kualitas pelaksanaan layanan pendidikan bagi peserta didik tunagrahita perlu diketahui sejauh mana sekolah telah memenuhi standar pelayanan minimal. 


\section{RUMUSAN MASALAH}

Masalah dalam penelitian ini dirumuskan sebagai berikut " Bagaimakah keterpenuhan Standar Pelayanan Minimal Sekolah Luar Biasa Tunagrahita di Kota Makassar?"

\section{TUJUAN PENELITIAN}

Tujuan penelitian ini adalah untuk mengetahui Keterpenuhan Standar Pelayanan Minimal Sekolah Luar Biasa Tunagrahita di Kota Makassar

\section{TINJAUAN PUSTAKA}

\section{Konsep Ketunagrahitaan}

Istilah tunagrahita digunakan untuk menggambarkan anak-anak dengan hambatan intelektual dan hambatan dalam prilaku adaptif. Tunagrahita adalah anak yang secara nyata mengalami hambatan dan keterbelakangan perkembangan intelektual jauh di bawah rata-rata (Nakata; 2003). Istilah intellectual disability digunakan untuk menandai ketunagrahitaan, yang diartikan: (1) mereka yang terlambat perkembangan intelektualnya, yang kesulitan mengemukakan maksudnya pada orang lain, dan mereka yang memerlukan tingkat bantuan yang sering dalam kehidupan sehari-hari; (2) mereka yang terlambat tingkat perkembangan intelektualnya yang disertai dengan kesulitan untuk beradaptasi dalam kehidupan sosial secara signifikan.

Batasan tunagrahita telah dikemukakan oleh berbagai asosiasi antara lain oleh AAIDD, yang mengemukakan istilah Intellectual Disabilities (ID) untuk hambatan intelektual, yang sebelumnya mengistilahkan dengan Mental Retardation (MR). Hal itu dikemukakan oleh American Association on Intelectual and Developmental Disabilities (AAIDD) melalui Schalock et al., 2010 (Kauffman \& Hallahan, 2011: 176) "characterized by significant limitation both in intelectual functioning and in adaptive behavior as expressed in conceptual, social, and practical adaptive skills."

Sistem penyelenggaraan pendidikan bagi anak tunagrahita secara umum dapat ditempuh dengan segregasi, integrasi, dan inklusi. Segregasi bermakna bahwa penyelenggaraan pendidikan anak tunagrahita terpisah secara eksklusif dengan anak reguler. Artinya, anak tunagrahita menerima pembelajaran hanya dengan teman sejenis kelaianannya dan tidak mengalami pembelajaran bersama-sama dengan anak reguler, mereka belajar pada sekolah khusus atau kelas khusus dengan guru khusus dan program pendidikan atau kurikulum khusus. Integrasi bermakna bahwa penyelenggaraan pendidikan anak tunagrahita tidak terpisah dengan anak reguler, tetapi mereka bersama-sama belajar dengan anak reguler di sekolah reguler dengan menyesuaikan diri pada tatanan pendidikan tempat mereka belajar, jadi anak tunagrahita yang menyesuaikan diri pada lingkungan dan kondisi sekolah, bukan lingkungan atau sekolah yang menyesuaikan pada kebutuhan belajar anak tunagrahita. Inklusi bermakna bahwa penyelenggaraan pendidikan anak tunagrahita tidak terpisah dengan anak reguler, tetapi mereka bersama-sama belajar dengan anak reguler di sekolah reguler, bukan anak yang menyesuaikan diri pada lingkungan dan kondisi sekolah tetapi sekolahlah yang menyesuaikan pada 
Pada sisi lain, anak tunagrahita juga memiliki perkembangan yang unik dalam berbagai segi, baik dalam segi fisik, sosial maupun lainnya. Dengan keunikan yang mereka miliki, mereka tidak bisa diperlakukan yang sama antar mereka, khususnya dalam pembelajaran..Artinya, program pendidikan pada mereka amat individual, yang berbeda dengan anak kebutuhan khusus lainnya dan dengan anak regular. Perbedaan implementasi tersebut terkait dengan penjenjangan (level capaian), kelas (grade), metode dan strategi pembelajaran, materi pembelajaran, dan tujuan pendidikan yang ingin dicapai. Dalam konteks ini kelas dipandang kurang relevan dan penggolongan kategori ringan dan kategori sedang tidak diperlukan, hanya pengelompokkan (grouping) fleksibel dan temporer yang diperlukan sehingga bisa saja A pada mata pelajaran IPA belajar bersama denngan B dan dalam mata pelajaran IPS A belajar bersama dengan C, bukan dengan B atau sendirian jika peserta didiknya cuma dua orang.

\section{Standar Nasional Pendidikan}

Standar Nasional Pendidikan adalah kriteria minimal tentang sistem pendidikan di seluruh wilayah hukum Negara Kesatuan Republik Indonesia. Standar Nasional Pendidikan terdiri dari :

- Standar Kompetensi Lulusan

- Standar Isi

- Standar Proses

- Standar Pendidikan dan Tenaga Kependidikan

- Standar Sarana dan Prasarana

- Standar Pengelolaan

- Standar Pembiayaan Pendidikan

- Standar Penilaian Pendidikan

Fungsi dan Tujuan Standar :

- Standar Nasional Pendidikan berfungsi sebagai dasar dalam perencanaan, pelaksanaan, dan pengawasan pendidikan dalam rangka mewujudkan pendidikan nasional yang bermutu

- Standar Nasional Pendidikan bertujuan menjamin mutu pendidikan nasional dalam rangka mencerdaskan kehidupan bangsa dan membentuk watak serta peradaban bangsa yang bermartabat.

- Standar Nasional Pendidikan disempurnakan secara terencana, terarah, dan berkelanjutan sesuai dengan tuntutan perubahan kehidupan lokal, nasional, dan global.

\section{Standar Pelayanan Minimal SLB Tunagrahita}

Standar Pelayanan Minimal SLB Tunagrahita merupakan penjabaran standar nasional pendidikan yang dikembangkan untuk sekolah luar biasa tunagrahita. Isi Standar Pelayanan Minimal SLB Tunagrahita meliputi delapan standar sebagaimana standar nasiomal pendidikan. 


\section{Standar Isi}

Standar Isi mencakup lingkup materi minimal dan tingkat kompetensi minimal untuk mencapai kompetensi lulusan minimal pada jenjang dan jenis pendidikan tertentu. Standar isi tersebut memuat kerangka dasar dan struktur kurikulum, beban belajar, kurikulum tingkat satuan pendidikan, dan kalender pendidikan. Kurikulum Tunagrahita dikembangkan oleh satuan pendidikan sesuai dengan karakteristik peserta didik yang menekankan pada aspek keterampilan dan kemandirian. Sekolah melaksanakan pengembangan kurikulum dengan melibatkan pihak-pihak yang terkait, yaitu guru, konselor, kepala sekolah, komite sekolah, dan nara sumber. Sekolah mengembangkan kurikulum berdasarkan prinsip-prinsip pengembangan sikap spiritual, sikap sosial, pengetahuan praktis dan fungsional, serta keterampilan.

2. Standar Kompetensi Lulusan

Standar Kompetensi Lulusan (SKL) merupakan kriteria kualifikasi kemampuan peserta didik yang mencakup seperangkat sikap, pengetahuan, dan keterampilan yang harus dimiliki, dihayati, dan dikuasai oleh peserta didik setelah mempelajari suatu muatan pembelajaran, menamatkan suatu program, atau menyelesaikan satuan pendidikan tertentu. Standar Kompetensi Lulusan sebagai acuan utama dalam mengembangkan Standar Isi, Standar Proses, Standar Penilaian Pendidikan, Standar Pendidik dan Tenaga Kependidikan, Standar Sarana dan Prasarana, Standar Pengelolaan, dan Standar Pembiayaan. Dengan demikian, setiap standar harus memiliki indikator ketercapaiannya dan setiap indikator merupakan acuan mutu pendidikan di Indonesia. Selain itu, Standar Kompetensi Lulusan juga digunakan sebagai pedoman penilaian dalam penentuan kelulusan peserta didik dari satuan pendidikan pada jenjang pendidikan dasar dan menengah.

\section{Standar Proses}

Silabus sebagai acuan pengembangan RPP memuat identitas mata pelajaran atau tema pelajaran, Kompetensi Inti (KI), Kompetensi Dasar (KD), materi pembelajaran, kegiatan pembelajaran, penilaian, alokasi waktu, dan sumber belajar. Silabus dikembangkan oleh satuan pendidikan berdasarkan Standar Isi (SI) dan Standar Kompetensi Lulusan (SKL), serta panduan penyusunan Kurikulum Tingkat Satuan Pendidikan (KTSP).

Dalam pelaksanaannya, pengembangan RPP SDLB Tunagrahita dan SMPLB Tunagrahita disusun oleh para guru secara mandiri atau berkelompok di sekolah.

Setiap guru pada SDLB Tunagrahita dan SMPLB Tunagrahita berkewajiban menyusun RPP secara lengkap dan sistematis agar pembelajaran berlangsung secara interaktif, inspiratif, menyenangkan, menantang, memotivasi peserta didik tunagrahita tunagrahita untuk berpartisipasi aktif 
4. Standar Kompetensi Pendidik Dan Tenaga Kependidikan (PTK)

Pendidik

Pendidik harus memiliki kualifikasi akademik pendidikan minimum diploma empat (D-IV) atau sarjana (S1) program pendidikan khusus atau sarjana yang sesuai dengan mata pelajaran yang diajarkan/diampu, dan diperoleh dari program studi yang terakreditasi.

Jumlah guru memenuhi persyaratan

Kompetensi guru

a) Kompetensi pedagogik sebagai agen pembelajaran

- Mampu merencanakan pembelajaran sesuai dengan prinsip-prinsif pembelajaran.

- Pelaksanaanpembelajaran sesuai dengan prinsip-prinsip pembelajaran

- Kompetensi mengevaluasi pembelajaran sesuai dengan prinsip-prinsip pembelajaran

b) Kompetensi kepribadian sebagai agen pembelajaran Memiliki integritas kepribadian dan tindakan

c) Kompetensi sosial sebagai agen pembelajaran Berkomunikasisecaraefektifdansantundengansesama guru, tenagakependidikan, danorangtuasiswa.

d) Kompetensi profesional sebagai agen pembelajaran

- Menguasai materi pelajaran

- Kompetenmelakukan penelitian

- Kompeten dalam menulisankaryailmiah

Tenaga Kependidikan

Kepala Sekolah

- Kualifikasi pendidikan kepala sekolah minimal D IV atau S1 kependidikan atau nonkependidikan

- Ijazah kepala sekolah berasal dari PT yang terakreditasi

- Memiliki sertifikat sebagai kepala sekolah

- Memiliki kemampuan manajerial yang ditunjukkan dengan keberhasilan mengelola siswa dan lainnya

- Memiliki kemampuan untuk melakukan supervisi dan montoring.

Tenaga Administrasi

Tenaga administrasi mempunyai kualifikasi:

- Pendidikan minimum lulusan SMA atau yang sederajat

- Memiliki sertifikat kepala tenaga administrasi sekolah bagi PNS

- Pelaksana Urusan Administrasi Umum untuk SD/MI/ SDLB Pendidikan minimal lulusan SMA atau yang sederajat 
Tenaga Perpustakaan

Setiap SDLB C memiliki sekurang-kurangnya satu tenaga perpustakaan yang berpendidikan minimal SMA/yang sederajat dan bersertifikat kompetensi pengelolaan perpustakaan

Sekolah Mempunyai Penjaga Sekolah, memiliki kualifikasi akademik pendidikan minimal SD.

5. Standar Sarana dan Prasarana

Lahan

a) Satu SDLB Tunagrahita memiliki sarana dan prasarana yang dapat melayani minimum 6 rombongan belajar, dan satu SMPLB Tunagrahita memiliki sarana dan prasarana yang dapat melayani minimum 3 rombongan belajar peserta didik Tunagrahita

b) Diupayakan lahan untuk SBLB/SMPLB Tunagrahita terletak di lokasi yang memungkinkan akses yang mudah ke fasilitas kesehatan. Lahan terhindar dari potensi bahaya yang mengancam kesehatan dan keselamatan jiwa, serta memiliki akses untuk penyelamatan dalam keadaan darurat dengan kendaraan roda empat, tidak berada di dalam garis sempadan sungai dan jalur kereta api.

\section{Ruang Kelas}

Satu ruang kelas SDLB Tunagrahita atau SMPLB Tunagrahita menampung satu rombongan belajar. Setiap rombongan belajar terdiri sebanyak-banyaknya 5 siswa SDLB Tunagrahita, dan 8 siswa untuk SMPLB Tunagrahita. Rasio minimum luas ruang kelas adalah 3 $\mathrm{m}^{2} /$ peserta didik. Untuk rombongan belajar dengan peserta didik kurang dari 5 orang, luas minimum ruang kelas adalah $15 \mathrm{~m}^{2}$ dengan lebar minimum ruang kelas adalah $3 \mathrm{~m}$.

Ruang kelas untuk setiap rombongan belajar dilengkapi dengan meja dan kursi yang cukup untuk peserta didik dan guru serta papan tulis penunjang yang terdiri dari ruang pimpinan, ruang guru, dan ruang tata usaha.

\section{Ruang Pimpinan}

Ruang pimpinan berfungsi sebagai tempat melakukan kegiatan pengelolaan SDLB, dan/atau SMPLB, pertemuan dengan sejumlah kecil guru, orang tua murid, unsur komite sekolah, petugas dinas pendidikan, atau tamu lainnya.

Luas minimum ruang pimpinan adalah $12 \mathrm{~m}^{2}$ dan lebar minimum adalah $3 \mathrm{~m}$. Ruang pimpinan mudah diakses oleh guru dan tamu sekolah, serta dapat dikunci dengan baik. 
a. Ruang Guru

Ruang guru berfungsi sebagai tempat guru bekerja dan istirahat serta menerima tamu, baik peserta didik maupun tamu lainnya.

Rasio minimum luas ruang guru adalah $4 \mathrm{~m}^{2} /$ pendidik dan luas minimum adalah $32 \mathrm{~m}^{2}$.

Ruang guru mudah dicapai dari halaman SDLB, dan/atau SMPLB ataupun dari luar lingkungan sekolah, serta dekat dengan ruang pimpinan.

b. Ruang Tata Usaha

Ruang tata usaha berfungsi sebagai tempat kerja petugas untuk mengerjakan administrasi SDLB, dan/atau SMPLB.

Rasio minimum luas ruang tata usaha adalah $4 \mathrm{~m} 2 /$ petugas dan luas minimum adalah $16 \mathrm{~m} 2$. Ruang tata usaha mudah dicapai dari halaman SDLB, dan/atau SMPLB ataupun dari luar lingkungan sekolah, serta dekat dengan ruang pimpinan.

c. Ruang Keterampilan

Di setiap SMPLB Tunagrahita tersedia minimal 3 ruang keterampilan yang dilengkapi dengan meja dan kursi yang cukup untuk 8 peserta didik. Di setiap ruang keterampilan minimal tersedia satu set peralatan keterampilan untuk praktek peserta didik.

d. Ruang Bina Diri

Di setiap SDLB Tunagrahita dan/atau SMPLB Tunagrahita tersedia 1 ruang bina diri dengan luas minimum $24 \mathrm{~m} 2$, yang berfungsi sebagai tempat kegiatan pembelajaran bina diri yang meliputi :

- Merawat diri: Makan, minum, menjaga kebersihan badan, buang air

- Mengurus diri: Berpakaian dan berhias diri

- Okupasi: Melakukan kegiatan sehari-hari yang meliputi mencuci dan menyeterika baju, menyemir sepatu, membuat minuman, memasang sprei, dan membersihkan lantai.

e. Perpustakaan

Ruang perpustakaan berfungsi sebagai tempat kegiatan peserta didik, guru dan orangtua peserta didik memperoleh informasi dari berbagai jenis bahan pustaka dengan membaca, mengamati dan mendengar, dan sekaligus tempat petugas mengelola perpustakaan.

Ruang perpustakaan dilengkapi jendela untuk memberi pencahayaan yang memadai untuk membaca buku, dan terletak di bagian sekolah yang mudah dicapai. 
6. Standar Pengelolaan

Perencanaan Program

1) Sosialisasi visi, misi \& Tujuan sekolah

- Melaksanakan sosialisasi visi, misi dan tujuan sekolah kepada semua warga sekolah

- Warga sekolah menunjukkan pemahaman terhadap visi, misi dan tujuan sekolah

- Melaksanakan sosialisasi KTSP sekolah kepada semua warga sekolah

2) Kepemilikan rencana kerja sekolah

- Sekolah memiliki dokumen rencana kerja sekolah dalam bentuk RKS (Rencana Kerja Sekolah 4-tahunan) dan RKA-S (Rencana Kegiatan dan Anggaran sekolah) atau rencana kerja tahunan

- Penyusunan rencana kerja sekolah (RKS) memperhatikan pertimbangan Komite Sekolah, disetujui oleh Dewan Pendidik, dan disahkan berlakunya oleh Dinas Pendidikan kab/kota atau oleh penyelenggara sekolah bagi sekolah swasta

- Rencana kerja sekolah mendukung pengembangan karir guru

3) Program peningkatan mutu sekolah

- Sekolah melaksanakan program peningkatan mutu sekolah

- Penyusunan program peningkatan mutu sekolah mendasarkan pada: hasil evaluasi diri, hasil akreditasi sekolah, dan hasil kelulusan siswa

Pelaksanaan Rencana Kerja

1) Realisasi visi dan misi ke dalam rencana kerja sekolah

Sekolah merealisasikan visi dan misi ke dalam pelaksanaan kegiatan pembelajaran, pengelolaan PTK, dan Pelaksanaan kegiatan kesiswaan

2) Sekolah menyusun pedoman pengelolaan sekolah

Sekolah menyusun pedoman-pedoman pengelolaan sekolah

3) Sekolah menciptakan lingkungan yg kondusif untuk kegiatan pembelajaran

Budaya dan lingkungan sekolah kondusif untuk pembelajaran

4) Sekolah menyediakan akses laporan pengelolaan keuangan sekolah secara transparan dan akuntabel

Warga sekolah dapat mengakses laporan pengelolaan keuangan sekolah secara transparan dan akuntabel

5) Sekolah menjalin kemitraan dengan lembaga lain

Sekolah menjalin kemitraan dengan lembaga lain untuk mendukung implementasi rencana kerja sekolah

7. Standar Pembiayaan

Pembiayaan pendidikan terdiri atas biaya investasi, biaya operasi, dan biaya personal. 
Biaya investasi satuan pendidikan sebagaimana dimaksud di atas meliputi biaya penyediaan sarana dan prasarana, pengembangan sumberdaya manusia, dan modal kerja tetap.

Biaya personal sebagaimana dimaksud pada di atas meliputi biaya pendidikan yang harus dikeluarkan oleh peserta didik untuk bisa mengikuti proses pembelajaran secara teratur dan berkelanjutan.

Biaya operasi satuan pendidikan sebagaimana dimaksud di atas meliputi:

- Gaji pendidik dan tenaga kependidikan serta segala tunjangan yang melekat pada gaji,

- Bahan atau peralatan pendidikan habis pakai, dan

- Biaya operasi pendidikan tak langsung berupa daya, air, jasa telekomunikasi, pemeliharaan sarana dan prasarana, uang lembur, transportasi, konsumsi, pajak, asuransi, dan lain sebagainya

\section{Standar Penilaian Pendidikan}

Perangkat penilaian:

1) Menyusun perangkat penilaian berupa kisi-kisi, format penilaian, dan laporan hasil belajar/latihan.

2) Menyusun rancangan jadwal pelaksanaan penilaian.

3) Memiliki dokumen laporan proses dan hasil belajar/latihan peserta didiktunagrahita.

Teknik Penilaian:

1) Rancangan penilaian dilakukan dengan menggunakan teknik penilaian otentik yang berupa penilaian kinerja untuk menilai hasil karya peserta didik tunagrahitabaik berupa unjuk kerja atau perbuatan, penilaian portofolio untuk melihat kumpulan pekerjaan peserta didiktunagrahitaserta catatan kemajuan belajar, dan penilaian tertulis untuk melihat kemampuan peserta didiktunagrahita terhadap materi yang telah dipelajari.

2) Teknik penilaian dilakukan sesuai dengan kompetensi dasar yang harus dikuasai peserta didiktunagrahitaserta penilaian kompetensi keterampilan berdasarkan kontrak belajar/latihan.

Pelaksanaan Penilaian:

1) Penilaian oleh pendidik

- Penilaian dilakukan sesuai dengan kompetensi dasar yang harus dikuasai oleh peserta didik tunagrahita dan penilaian kompetensi terhadap keterampilan yang dipelajari peserta didik tunagrahita berdasarkan kontrak belajar/latihan.

- Mengolah dan menganalisis hasil penilaian untuk mengetahui kemajuan dan kesulitan belajar yang dihadapi oleh peserta didiktunagrahita. 
- Memberikan remedial (perbaikan) pada peserta didiktunagrahitayang belum mencapai kompetensi dasar yang telah ditentukan

2) Penilaian oleh sekolah

- Satuan pendidikan mengadakan rapat dewan guru untuk mendiskusikan dan menentukan nilai akhir peserta didiktunagrahita.

- Satuan pendidikan melaporkan hasil penilaian setiap akhir semester kepada semua orang tua/wali peserta didiktunagrahita.

- Satuan pendidikan mengupayakan jalinan kerjasama dengan lembaga pendidikan/lembaga pelatihan lain untuk penerbitan sertifikat kelulusan pada mata pelajaran (bidang keterampilan) tertentu yang kelulusannya diuji melalui uji kompetensi.

Hasil Penilaian

1) Peserta didik minimal mencapai batas kontrak belajaryang ditetapkan olehsekolah.

2) Peserta didik minimal mencapai batas kontraklatihan minimal yang ditetapkan oleh pusat layanan keterampilan.

3) Penilaian berorientasi pada perubahan yang terjadi pada semua aspek perkembangan peserta didik dan keterampilan yang dikuasai sebagai proses dan hasil belajarnya.

\section{METODE PENELITIAN}

Penelitian ini adalah penelitian deskriptif, jenis ekspost-facto dengan menggunakan model penelitian survey berdasarkan jawaban responden atas daftar pertanyaan yang diberikan. Daftar pertanyaan tersebut terkait dengan pengukuran peresepsi terhadap pelaksanaan Standar Pelayanan Minimal di Sekolah Luar Biasa Tunagrahita di Kota Makassar.

Penelitian ini akan dilaksanakan di sekolah luar biasa yang menyelenggarakan pendidikan bagi peserta didik tunagrahita. Penelitian ini akan dilaksanakan pada bulan Juni 2016.

Populasi dalam penelitian ini adalah semua sekolah luar biasa yang menyelenggarakan pendidikan bagi peserta didik tunagrahita di Kota Makassar. Pengumpulan data dilakukan dengan menggunakan kuesioner. Instrumen yang digunakan adalah instrumen Standar Pelayanan Minimal Sekolah Luar Biasa untuk Peserta Dididk Tunagrahita yang dikembangkan oleh APPKhI kerjasama dengan Direktorat PPKLK Dikdasmen Kemendikbud.

Untuk menjawab pertanyaan penelitian yang telah diajukan, maka data yang telah dikumpulkan dianalisis dengan menggunakan teknik analisis Analisis deskreptif. 


\section{HASIL PENELITIAN}

\section{Peran Sekolah}

Berdasarkan hasil analisis deskriptif diketahui bahwa 93\% responden menyatakan bahwa sekolah telah memenuhi standar isi. Hanya $7 \%$ responden yang menyatakan bahwa sekolah tidak memenuhi standar isi. Dengan demikian dapat disimpulkan bahwa Sekolah Luar Biasa (SLB) Tunagrahita di Kota Makassar telah memenuhi Standar Isi. Namun demikian masih terdapat satu atribut dari standar isi yang memperoleh respon tidak baik pada batas toleransi 25\%, yaitu Sekolah mengimplementasikan program kemandirian/persiapan kerja, ini menunjukkan ada sebanyak $25 \%$ responden yang menyatakan bahwa sekolah tidak mengimplementasikan program kemandirian/persiapan kerja.

Berdasarkan hasil analisis deskriptif terhadap Standar Kompetensi Lulusan diketahui bahwa 96,4\% respon menyatakan bahwa sekolah telah memenuhi standar Kompetensi Lulusan (SKL). Hanya 3,6\% responden yang menyatakan bahwa sekolah tidak memenuhi SKL. Dengan demikian dapat disimpulkan bahwa Sekolah Luar Biasa (SLB) Tunagrahita di Kota Makassar telah memenuhi Standar Kompetensi Lulusan. Namun demikian masih terdapat tiga atribut dari SKL yang belum belum terpenuhi $100 \%$, yaitu Peserta didik menunjukan sikap yang baik; beriman, berahlak mulia, percaya diri, bertanggung jawab (87,5\%), Peserta didik tunagrahita memperoleh pengalaman belajar untuk menjalankan ajaran agama yang dianut sesuai dengan tahap perkembangannya $(87,5 \%)$ dan Peserta didik tunagrahita memperoleh pengalaman belajar dapat menunjukkan kecintaan dan kebanggaan terhadap bangsa, negara, dan tanah air Indonesia $(75 \%)$.

Rangkuman hasil analisis deskriptif respon sekolah terhadap keterpenuhan Standar Isi menunjukkan bahwa $82 \%$ respon menyatakan bahwa sekolah telah memenuhi standar proses. Terdapat 17,2\% responden yang menyatakan bahwa sekolah tidak memenuhi standar proses. Dengan demikian dapat disimpulkan bahwa Sekolah Luar Biasa (SLB) Tunagrahita di Kota Makassar belum sepenuhnya memenuhi Standar Proses. Terdapat tiga atribut standar proses yang perlu mendapat perhatian serius karena memperoleh respon tidak diatast 25\%, yaitu Setiap peserta didik tunagrahita memiliki buku teks pelajaran untuk semua tema yang ditetapkan Pemerintah (50\%), Setiap guru memiliki buku panduan guru yang ditetapkan oleh Pemerintah untuk semua tema sesuai dengan tugas mengajarnya $(37,5 \%)$, dan Sekolah memiliki buku teks pelajaran peserta didik tunagrahita yang ditetapkan oleh Pemerintah (25\%).

Rangkuman hasil analisis deskriptif respon sekolah terhadap keterpenuhan Standar Isi menunjukkan bahwa 87,5\% respon menyatakan bahwa sekolah telah memenuhi standar Pendidik dan Tenaga Kependidikan. Terdapat $12,5 \%$ responden yang menyatakan bahwa sekolah tidak memenuhi standar Pendidik dan Tenaga Kependidikan. Nampak hampir semua atribut standar Pendidik dan Tenaga Kependidikan memperoleh respon ya di bawah $100 \%$. Dengan demikian dapat disimpulkan bahwa Sekolah Luar Biasa (SLB) 
Tunagrahita di Kota Makassar belum sepenuhnya memenuhi Standar Pendidik dan Tenaga Kependidikan. Terdapat dua atribut standar Pendidik dan Tenaga Kependidikan yang perlu mendapat perhatian serius karena memperoleh respon tidak sebanyak 25\%, yaitu atribut no. 35 : Kepala sekolah memiliki kualifikasi akademik minimum diploma empat (D-IV) atau sarjana (S1) (25\%), atribut no. 38 : Sekolah memiliki tenaga perpustakaan sekolah (minimal SLTA/sederajat) minimal 1 orang $(25 \%)$.

Berdasarkan hasil analisis deskriptif Standar Sarana Prasarana diketahui bahwa 95,8\% respon menyatakan bahwa sekolah telah memenuhi standar Sarana Prasarana. Hanaya 4,2\% responden yang menyatakan bahwa sekolah tidak memenuhi standar Sarana Prasarana. Dengan demikian dapat disimpulkan bahwa Sekolah Luar Biasa (SLB) Tunagrahita di Kota Makassar telah memenuhi Standar Sarana Prasarana. Namun masih terdapat satu atribut standar Sarana Prasarana yang perlu mendapat perhatian serius karena memperoleh respon tidak sebanyak $25 \%$, yaitu atribut Sekolah memiliki ruang guru (25\%). Artinya masih ada Sekolah Luar Biasa (SLB) Tunagrahita di Kota Makassar yang belum memiliki ruang guru.

Berdasarkan hasil analisis deskriptif Standar Pengelolaan diketahui bahwa 97,9\% responden menyatakan bahwa sekolah telah memenuhi standar Pengelolaan. Hanya $2,1 \%$ responden yang menyatakan bahwa sekolah tidak memenuhi standar Pengelolaan. Dengan demikian dapat disimpulkan bahwa Sekolah Luar Biasa (SLB) Tunagrahita di Kota Makassar telah memenuhi Standar Pengelolaan.

Rangkuman hasil analisis deskriptif respon sekolah terhadap keterpenuhan Standar Pembiayaan diketahui bahwa 100\% responden menyatakan bahwa sekolah telah memenuhi standar Pembiayaan. Dengan demikian dapat disimpulkan bahwa Sekolah Luar Biasa (SLB) Tunagrahita di Kota Makassar telah memenuhi Standar Pembiayaan.

Rangkuman hasil analisis deskriptif respon sekolah terhadap keterpenuhan Standar Standar Penilaian Pendidik diketahui bahwa 93,75\% responden menyatakan sekolah telah memenuhi standar Penilaian Pendidik. Hanya 6,25\% responden yang menyatakan bahwa sekolah tidak memenuhi standar Penilaian Pendidik. Dengan demikian dapat disimpulkan bahwa Sekolah Luar Biasa (SLB) Tunagrahita di Kota Makassar telah memenuhi Standar Penilaian Pendidik. Namun demikian ada satu atribut standar Penilaian Pendidik yang memperoleh respon tidak sebesar 37,5\% yaitu atribut no. 68 : Sekolah mengupayakan jalinan kerjasama dalam menindaklanjuti bidang keterampilan peserta didik tunagrahita. Hal ini yang perlu mendapat perhatian serius dari pihak terkait.

\section{Peran Pemerintah}

Pemerintah dalam laporan penelitian ini adalah Pemerintah Daerah yang direpresentasikan oleh Dinas Pendidikan Kota Makassar. Analisis deskriptif 
meliputi delapan standar nasional pendidikan, yang dilakukan pada setiap dimensi keterpenuhan SPM Sekolah.

Rangkuman hasil analisis deskriptif peran Pemda terhadap keterpenuhan Standar Isi diketahui bahwa ada 56,25\% responden yang menyatakan bahwa Pemerintah Daerah tidak melalukan peran dalam pemenuhan standar isi Sekolah Luar Biasa (SLB) Tunagrahita di Kota Makassar. Terutama dalam hal mengimplentasikan program kemandirian/persiapan kerja siswa di SLB Tunagrahita $(87,5 \%)$.

Rangkuman hasil analisis deskriptif peran Pemda terhadap keterpenuhan Standar Proses diketahui responden menyatakan bahwa Pemda telah berperan sebanyak 56,25\% dalam pemenuhan standar Proses Sekolah Luar Biasa (SLB) Tunagrahita di Kota Makassar. Ada 43,25\% responden yang menyatakan bahwa Pemda tidak berperan dalam pemenuhan standar Proses Sekolah Luar (SLB) Tunagrahita di Kota Makassar. Terdapat tiga atribut standar proses yang tidak didukung oleh peran Pemda yaitu atribut Peran Pemda dalam dalam pengadaan buku teks pelajaran peserta didik tunagrahita yang ditetapkan oleh Pemerintah Buku Siswa dan Buku Guru) (62,5\%), Peran Pemda dalam penyusunan silabus, persiapan mengajar (RPP) (50\%), dan Peran pemda dalam pembuatan program semester, program tahunan $(50 \%)$.

Berdasarkan hasil analisis deskriptif terhadap standar Pendidik dan Tenaga Kependidikan diketahui responden menyatakan bahwa Pemda baru berperan sebanyak 43,75\% dalam pemenuhan standar Pendidik dan Tenaga Kependidikan Sekolah Luar Biasa (SLB) Tunagrahita di Kota Makassar. Ada $56,25 \%$ responden yang menyatakan bahwa Pemda tidak berperan dalam pemenuhan standar Pendidik dan Tenaga Kependidikan Sekolah Luar (SLB) Tunagrahita di Kota Makassar. Terdapat tiga atribut standar Pendidik dan Tenaga Kependidikan yang tidak didukung oleh peran Pemda yaitu atribut dalam pengadaan tenaga administrasi sekolah (minimal SLTA/sederajat) minimal 1 orang $(87,5 \%)$, Peran Pemda dalam pengadaan guru atau tenaga pengajar memiliki kualifikasi akademik minimal S1 (50\%), dan Peran Pemda dalam pengadaan guru yang memiliki kemampuan untuk melaksanakan asesmen pembelajaran $(50 \%)$.

Berdasarkan hasil analisis deskriptif Standar Sarana dan Prasarana diketahui responden menyatakan bahwa Pemda hanya berperan sebanyak 30,56\% dalam pemenuhan standar Sarana dan Prasarana Sekolah Luar Biasa (SLB) Tunagrahita di Kota Makassar. Ada 69,44\% responden yang menyatakan bahwa Pemda tidak berperan dalam pemenuhan standar Sarana dan Prasarana Sekolah Luar (SLB) Tunagrahita di Kota Makassar. Semua atribut standar Sarana dan Prasarana tidak didukung oleh peran Pemda. Hal yang paling menonjol adalah itribut: Peran Pemda dalam pengadaan ruang kelas sebanyak rombongan belajar, atribut no 13 : Peran Pemda dalam pengadaan ruang khusus untuk pengembangan keterampilan siswa, atribut: Peran Pemda dalam pengadaan tempat bermain/ruang terbuka, dan atribut: Peran Pemda dalam pengadaan fasilitas tempat peribadatan, 
responden menyatakan peran Pemda untuk masing-masing atribut tersebut hanya $25 \%$.

Rangkuman hasil analisis deskriptif peran Pemda terhadap keterpenuhan Standar Pengelolaan diketahui responden menyatakan bahwa Pemda hanya berperan sebanyak 58,33\% dalam pemenuhan standar Pengelolaan Sekolah Luar Biasa (SLB) Tunagrahita di Kota Makassar. Ada 41,67\% responden yang menyatakan bahwa Pemda belum berperan dalam pemenuhan standar Pengelolaan Sekolah Luar (SLB) Tunagrahita di Kota Makassar. Dengan demikian dapat disimpulkan bahwa Pemerintah Daerah belum sepenuhnya berperan dalam pemenuhan Standar Pengelolaan Sekolah Luar Biasa (SLB) Tunagrahita di Kota Makassar. Terdapat satu atribut standar Pengelolaan yang belum didukung oleh peran Pemda, yaitu atribut: Peran Pemda dalam penyusunan visi dan misi sekolah $(87,5 \%)$.

\section{KESIMPULAN}

Sekolah Luar Biasa (SLB) Tunagrahita di Kota Makassar belum semuanya memenuhi Standar Isi. Masih ada Sekolah yang belum mengimplementasikan program kemandirian/persiapan kerja. Pemerintah Daerah belum melalukan peran dalam pemenuhan standar isi Sekolah Luar Biasa (SLB) Tunagrahita di Kota Makassar. Terutama dalam hal mengimplentasikan program kemandirian/persiapan kerja siswa di SLB Tunagrahita.

Sekolah Luar Biasa (SLB) Tunagrahita di Kota Makassar telah memenuhi Standar Kompetensi Lulusan.

Sekolah Luar Biasa (SLB) Tunagrahita di Kota Makassar belum sepenuhnya memenuhi Standar Proses. Belum semua Sekolah memiliki buku teks pelajaran peserta didik tunagrahita yang ditetapkan oleh Pemerintah.

Pemerintah daerah belum sepernuhnya berperan dalam pemenuhan Standar Proses Sekolah Luar Biasa (SLB) Tunagrahita di Kota Makassar. Dukungan Pemerintah Daerah sangat diharapkan dalam hal pengadaan buku teks pelajaran dan buku guru untuk peserta didik tunagrahita yang ditetapkan oleh Pemerintah.

Sekolah Luar Biasa (SLB) Tunagrahita di Kota Makassar belum sepenuhnya memenuhi Standar Pendidik dan Tenaga Kependidikan. Terutama dalam hal kualifikasi akademik Kepala Sekolah.

Pemerintah Daerah kurang berperan dalam pemenuhan standar Pendidik dan Tenaga Kependidikan Sekolah Luar (SLB) Tunagrahita di Kota Makassar. Pemerintah Daerah sangat diharapkan dalam memberikan dukungan terhadap keterpenuhan Standar Pendidikan dan Tenaga Kependidikan terutama dalam hal pengadaan guru/tenaga pendidikan maupun tenaga kependidikan yang memenuhi kuantitas dan kualifikasi yang dipersyaratkan.

Sekolah Luar Biasa (SLB) Tunagrahita di Kota Makassar belum sepenuhnya memenuhi Standar Sarana Prasarana. Masih ada Sekolah yang belum memiliki ruang guru. Peran Pemerin Daerah dalam pemenuhan standar Sarana dan Prasarana Sekolah Luar Biasa (SLB) Tunagrahita di Kota Makassar juga masih 
rendah. Terutama dalam pengadaan ruang kelas, ruang khusus untuk pengembangan keterampilan siswa, dan pengadaan tempat bermain/ruang terbuka, serta pengadaan fasilitas tempat peribadatan.

Sekolah Luar Biasa (SLB) Tunagrahita di Kota Makassar belum sepenuhnya memenuhi Standar Pengelolaan. Pemerintah Daerah belum memfasilitasi Sekolah dalam penyusunan visi misi sekolah.

Sekolah Luar Biasa (SLB) Tunagrahita di Kota Makassar telah memenuhi Standar Penilaian Pendidik. Namun masih perlu mengupayakan jalinan kerjasama dalam menindaklanjuti bidang keterampilan peserta didik tunagrahita.

\section{DAFTAR PUSTAKA}

Instruksi Presiden Republik Indonesia Nomor 1 Tahun 2010 tentang Program Percepatan Pembangunan

Juran, Joseph M. \&Godfrey, A. Blanton. (1998). Juran's Quality Handbook. USA: The McGraw-Hill Companies, Inc.

Peraturan Pemerintah No.13 Tahun 2015 tentang Perubahan Kedua Atas PP No.19 tentang Standar Nasional Pendidikan

Peraturan Pemerintah Nomor 19 Tahun 2005 tentang Standar Nasional Pendidikan (Lembaran Negara Republik Indonesia Tahun 2005 Nomor 41, Tambahan Lembaran Negara Republik Indonesia Nomor 4496)

Permendikbud No. 20 Tahun 2016 tentang Standar Kompetensi Lulusan Pendidikan Dasar dan Menengah

Permendikbud No. 21 Tahun 2016 tentang Standar Isi Pendidikan Dasar dan Menengah yang memuat tentang Tingkat Kompetensi dan Kompetensi Inti

Permendikbud No. 22 Tahun 2016 tentang Standar Proses Pendidikan Dasar dan Menengah

Permendikbud No. 23 Tahun 2016 tentang Standar Penilaian Pendidikan

Sallis, Edward. (2002). TQM in Education. Third Edition. London: Kogan Page Ltd.

Undang-Undang Nomor 20 Tahun 2003 tentang Sistem Pendidikan Nasional (Lembaran Negara Republik Indonesia Tahun 2003 Nomor 78, Tambahan Lembaran Negara Republik Indonesia Nomor 4301) 